ORNLTM-12849

Dist. Category UC-1404

Chemical Technology Division

\title{
BIOPROCESSING IN NONAQUEOUS MEDIA CRITICAL NEEDS AND OPPORTUNITIES
}

\author{
Charles D. Scott \\ Timothy C. Scott \\ Bioprocessing Research and Development Center \\ Oak Ridge National Laboratory \\ Oak Ridge, Tennessee \\ Harvey W. Blanch \\ Chemical Engineering Department \\ University of California \\ Berkeley, California \\ Alexander M. Klibanov \\ Department of Chemistry \\ Massachusetts Institute of Technology \\ Cambridge, Massachusetts \\ Alan J. Russell \\ Center for Biotechnology \\ University of Pittsburgh \\ Pittsburgh, Pennsylvania
}

Date Published-January 1995

Prepared for

Biological and Chemical Technology Program

Office of Industrial Technologies

U. S. Department of Energy

Washington, D. C.

(DOE Budget Activity Number ED 370000 0)

Prepared by the

OAK RIDGE NATIONAL LABORATORY

Oak Ridge, Tennessee 37831

managed by

MARTIN MARIETTA ENERGY SYSTEMS, INC. for the

U.S. DEPARTMENT OF ENERGY

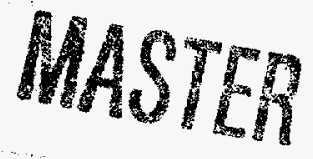

under contract DE-AC05-84OR21400 



\section{DISCLAIMER}

This report was prepared as an account of work sponsored by an agency of the United States Government. Neither the United States Government nor any agency thereof, nor any of their employees, make any warranty, express or implied, or assumes any legal liability or responsibility for the accuracy, completeness, or usefulness of any information, apparatus, product, or process disclosed, or represents that its use would not infringe privately owned rights. Reference herein to any specific commercial product, process, or service by trade name, trademark, manufacturer, or otherwise does not necessarily constitute or imply its endorsement, recommendation, or favoring by the United States Government or any agency thereof. The views and opinions of authors expressed herein do not necessarily state or reflect those of the United States Government or any agency thereof. 


\section{DISCLAIMER}

Portions of this document may be illegible in electronic image products. Images are produced from the best available original document. 


\section{CONTENTS}

1. EXECUTIVE SUMMARY $\ldots \ldots \ldots \ldots \ldots \ldots \ldots \ldots \ldots \ldots \ldots \ldots \ldots$

1.1 POTENTIAL IMPACT OF NONAQUEOUS BIOPROCESSING

1.2 RESEARCH STATUS . . . . . . . . . . . .

1.3 CRITICAL RESEARCH NEEDS AND OPPORTUNITIES ......... 2

1.3.1 Enhanced Biocatalysts .................. 3

1.3.2 Effects of Operating Environment on the Biocatalyst ..... 3

1.3.3 Advanced Bioreactor Concepts ................ 3

1.3.4 Bioprocessing System .................. 4

1.4 SUPPORT OF NONAQUEOUS BIOPROCESSING R\&D $\ldots \ldots \ldots \ldots 4$

2. INTRODUCTION .................................. 5

3. THE POTENTIAL IMPACT OF ENERGY-RELATED NONAQUEOUS BIOPROCESSING $\ldots \ldots \ldots \ldots \ldots \ldots \ldots \ldots \ldots, 7$

3.1 FOSSIL FUELS $\ldots \ldots \ldots \ldots \ldots \ldots \ldots \ldots \ldots \ldots \ldots \ldots$

3.2 CONVERSION OF RENEWABLE REEDSTOCKS ............. 8

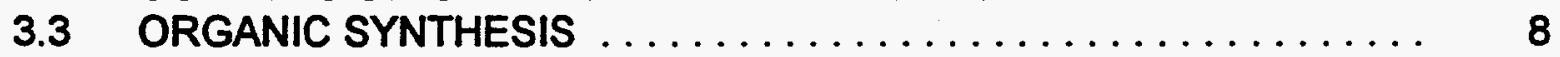

3.4 ENVIRONMENTAL CONTROL TECHNOLOGY $\ldots \ldots \ldots \ldots \ldots .9$

4. NONAQUEOUS BIOPROCESSING: AN OVERVIEW AND STATUS ..... 11

4.1 THE BIOPROCESSING SYSTEM $\ldots \ldots \ldots \ldots \ldots \ldots \ldots \ldots \ldots \ldots . \ldots \ldots$

4.2 BIOCATALYSIS IN ORGANIC LIQUIDS $\ldots \ldots \ldots \ldots \ldots \ldots \ldots \ldots \ldots$

4.2.1 Effects of Organic Solvents . . . . . . . . . . . . . . . 15

4.2.2 Effects of Interfaces ........................ 17

4.2.3 Chemical Modification of Biocatalysts ............... 18

4.2.4 Biocatalyst Engineering ....................... 19

4.2.5 Advanced Bioreactor Concepts .................. 19

4.3 BIOCATALYSIS IN ORGANIC GASES $\ldots \ldots \ldots \ldots \ldots \ldots \ldots \ldots 21$

4.3.1 Biocatalytic Systems ...................... 22

4.3.2 Advanced Bioreactor Concepts .................... 22

4.4 BIOCATALYSIS IN SUPERFICIAL FLUID SYSTEMS . . . . . . . 23

4.4.1 Biocatalytic Systems $\ldots \ldots \ldots \ldots \ldots \ldots \ldots \ldots \ldots \ldots .23$

4.4.2 Advanced Bioreactor Concepts .................. 24

5. RESEARCH AND DEVELOPMENT NEEDS AND OPPORTUNITIES $\ldots \ldots 25$

5.1 ENHANCED BIOCATALYSTS $\ldots \ldots \ldots \ldots \ldots \ldots \ldots \ldots \ldots \ldots$ 
CONTENTS

(Continued)

Page

5.2 EFFECT OF OPERATING ENVIRONMENT ON THE BIOCATALYST ........................ 26

5.3 ADVANCED BIOREACTOR CONCEPTS $\ldots \ldots \ldots \ldots \ldots \ldots \ldots, 27$

5.4 BIOPROCESSING SYSTEM .................. 28

6. SUPPORT FOR RESEARCH AND DEVELOPMENT ........... 29

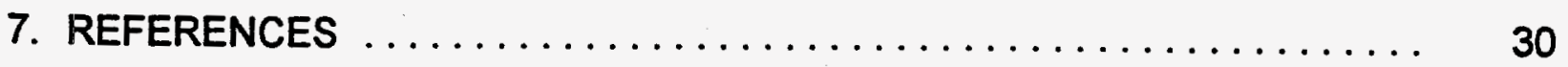




\section{EXECUTIVE SUMMARY}

Chemical conversion processes are pervasive in the U.S. industry. Whether they are used to make intermediate or final products or to remove hazardous materials from process waste streams, they are critical elements in the processing industries. Because of the mild reaction conditions, unique specificity, and selectivity, advanced processing concepts utilizing biocatalytic conversions are now being considered for many industrial uses, including those directly related to energy production and efficiency.

Almost all bioprocessing systems currently used by industry utilize the biocatalysts (microorganisms or extracted enzymes) in a "natural" aqueous environment. This has resulted in many important large-scale applications, particularly in the fermentation and pharmaceutical industries. An exciting new area of bioprocessing research is now evolving - the use of biocatalysts in contact with nonaqueous media such as organic liquids or gases, or supercritical fluids. Such approaches could result in additional bioprocessing concepts that would result in a much broader range of utility, especially in energy production and energy-efficient conversion processes in the chemical industry. In fact, a whole new industry may be evolving.

\subsection{THE POTENTIAL IMPACT OF NONAQUEOUS BIOPROCESSING}

Nonaqueous bioprocessing could provide important alternatives for the processing of fossil fuels (e.g., coal liquefaction, sulfur removal from petroleum, etc.); synthesis of energy-rich organic chemicals (e.g., organic synthesis in solvents or supercritical fluids); and the conversion of alternative feedstocks to fuels and chemicals (e.g., biomass processing in contact with organic solvents or supercritical fluids). Such potential bioprocessing alternatives could ultimately represent well over $\$ 100 \mathrm{~B}$ in annual sales. It is also expected that such 
advanced systems will find important applications in environmental control technology, especially that required for energy production (e.g., the removal of organic vapors from effluent streams). The potential applications for this new nonaqueous approach to bioprocessing is much greater than that of the existing bioprocessing systems in use throughout industry.

\subsection{RESEARCH STATUS}

Although nonaqueous bioprocessing has been postulated for some time, there is now a growing interest for a variety of applications. This has resulted in intriguing laboratory investigations, particularly during the last decade, that indicated some very important areas of potential utility. Most of these studies have been quite preliminary and limited in scope; therefore, the fundamental scientific and engineering principles for nonaqueous bioprocessing have not yet been established. It is proposed that the necessary bridging research and development (R\&D) be carried out that will provide the basis for subsequent nonaqueous bioprocess development for a variety of applications, especially those that will enhance energy production and process efficiency, and encourage the use of renewable sources of energy. The results of this effort could be the basis for the establishment of a broad range of new processing options.

\subsection{CRITICAL RESEARCH NEEDS AND OPPORTUNITIES}

Although there is increasing industrial interest in nonaqueous bioprocessing, this evolving R\&D area is still not well understood and the necessary biological and engineering principles have not been sufficiently well established to allow enlightened process development, process design, and scale-up. The most effective nonaqueous bioprocessing concepts will utilize enhanced biocatalysts, in advanced bioreactors, operating under optimum conditions, that are well-integrated into the total bioprocessing system. There are critical research and development needs in each of these areas. 


\subsubsection{Enhanced Biocatalysts}

Only a very limited number of microorganisms and enzymes have been studied for nonaqueous bioprocesses. Literally thousands more are candidates, and many of these can be isolated from environments in contact with nonaqueous solvents. Screening tests should be carried out to identify potential new biocatalysts. Entirely different types of biocatalysts that are more compatible with nonaqueous media should also be developed and studied using such techniques as protein engineering, mutagenesis, and chemical modification.

\subsubsection{Effects of Operating Environment on the Biocatalyst}

Optimum conditions for the nonaqueous biocatalytic process must be established, including the usual chemical and physical factors as well as the impact of the nonaqueous media itself. Many of these parameters can be studied as generic factors, but some will be very process specific. Of particular interest will be their effects on enzyme structure and biocatalytic mechanisms.

\subsubsection{Advanced Bioreactor Concepts}

Efficient bioreactors must be available to economically exploit a proposed nonaqueous bioprocess. Bioreactor concepts developed for aqueous processing, especially those for continuous operation, can be used to a degree, but the nonaqueous phase must also be accommodated. Some concepts will require biocatalyst immobilization, and other approaches will necessitate the use of multiple phases (e.g., dispersion and coalescence in liquid-liquid systems) with enhanced mass transfer. Not only will new bioreactor configurations and operating procedures be required, but predictive models that can be used for design and scaleup will be necessary. 


\subsubsection{Bioprocessing System}

Both upstream and downstream processing will require different techniques for nonaqueous bioprocessing than are used for conventional biotechnology. This will necessitate new procedures for introducing the substrates and biocatalysts, as well as recovering products, and other processing components from systems with multiple phases. New approaches to efficient process monitoring and control will also be required, especially when utilizing supercritical fluids and liquid-liquid emulsions.

\subsection{SUPPORT FOR NONAQUEOUS BIOPROCESSING R\&D}

Although there is increasing interest in nonaqueous bioprocessing, support for research and development is evolving very slowly. Limited government support has been the primary driving force in this innovative field. A small amount of fundamental research is supported by the National Science Foundation, and some applied research and even less fundamental research is supported by the U. S. Department of Energy (DOE) and the U. S. Department of Defense. As nonaqueous bioprocessing becomes more viable, bridging research and development (perhaps via the DOE Office of Industrial Technologies) becomes increasingly more important to establish the necessary technology base that will allow the expanded application of this new approach to bioprocessing. Such an effort could productively use an initial $\$ 5 \mathrm{M} /$ year level that should be expanded to at least $\$ 10 \mathrm{M} /$ year over a 3-year period. As a result of such an initiative, industrial exploitation would be accelerated, renewable energy and enhanced energy efficiency would be encouraged, and a new industry would be born. 


\section{INTRODUCTION}

Biological processes are simply one type of chemical conversion, a class of processing technique that is pervasive in the U.S. industry. Innovative bioprocessing concepts are now being considered for many industrial uses, including those relevant to energy production and efficiency. ${ }^{1-6}$. For application to energy processes, there will probably be two broad classes of feed materials or substrates for biological processing: fossil fuels, mainly coal, petroleum, and natural gas, and products derived from these materials; ${ }^{7 \cdot 9}$ and renewable feedstocks, such as grain, woody biomass, and combustible waste materials. ${ }^{10.11}$ In addition, biological processes for the cleanup of energy-related process effluents and the remediation of contaminated sites are perhaps the only way to handle the current need for environmentally benign energy production. ${ }^{25,12,13}$ One of the greatest potentials for advanced bioprocessing is in the chemical industry, especially the organic chemical industry. This could result in important process alternatives that would provide energy-efficient approaches with minimal environmental impact.

The ability to use biocatalysts in nonnatural environments, such as nonaqueous media, would facilitate the application of bioprocesses in a wide range of operations. Most biocatalysts are amazingly specific, and it is this ability to carry out a reaction on a single substrate or, conversely, to utilize multiple substrates to produce a single product or product family, that gives them wide applicability. In the context of this report, the nonaqueous media that are considered are organic liquids ${ }^{1417}$ and gases, ${ }^{18,19}$ and supercritical fluids. ${ }^{20,21}$ Such systems could be particularly useful for energy transformations and efficiency, especially in the processing of fossil fuels, synthesis of energy-rich organic chemicals, and the conversion of alternative feedstocks to fuels and chemicals, as well as the processing of some effluent streams. In these cases, the ability of biocatalysts to modify complex organic mixtures and transform these 
feed materials into useful products will be exploited. Applications in some biomedical areas are also expected to be important, ${ }^{15.16}$ and there will probably be many common elements among all of the application areas.

An important limitation to the use of conventional biological processes in the aforementioned applications arises from the observation that many of the feedstocks and/or resulting products have only limited or negligible water solubility. Similarly, many of the hazardous materials contained within waste streams generated during these activities - such as tars or polyaromatic hydrocarbons - are marginally water soluble at best. Biocatalysts, such as microorganisms (which may be considered as complex, multifunctional, enzyme systems) or isolated enzymes, are designed by nature to be effective in an aqueous medium, which would suggest that they are poorly suited for use in any application that requires function within a nonaqueous matrix. However, intriguing results from a growing body of literature show that it is possible to use certain biocatalysts in contact with many nonaqueous media. ${ }^{1-21}$

The precise bioreaction mechanisms within these nonnatural environments have not been well defined, effects on biocatalyst activity are frequently indeterminate, and contacting concepts have not been thoroughly studied or optimized. It is proposed that an R\&D effort be organized and supported to provide for a better understanding of the underlying biological and engineering principles of nonaqueous bioprocessing with a particular emphasis on energy-related and environmental-related applications. This should provide a solid basis for the further development and ultimate commercialization of such innovative bioprocessing concepts. 


\section{THE POTENTIAL IMPACT OF ENERGY-RELATED NONAQUEOUS BIOPROCESSING}

Bioprocessing has been, or is currently being, considered for use in several energy-related applications, and there is an ever greater potential for future work in this area. As indicated above, nonaqueous bioprocessing is expected to have many energy-related applications. These areas will include: (1) processing of fossil fuels; (2) conversion of renewable feedstock to fuels and chemicals; (3) organic synthesis for high-energy-content chemicals; and (4) environmental control technology. A significant amount of spin-off technology will also be expected to impact the biomedical and food industries.

\subsection{FOSSIL FUELS}

Many new bioprocessing approaches are being considered for application to fossil fuels, and several of these will require nonaqueous systems. ${ }^{9}$ The conversion of coal to liquids, especially in a reducing atmosphere, is best carried out in organic solvents in the absence of an aqueous phase..$^{8,922,23}$ It may also be possible to use supercritical fluids as the reaction medium for coal bioconversion processes. Subsequent bioprocessing to upgrade the liquid product and remove heteroatoms and metals will also require nonaqueous processing. ${ }^{24,25}$ Bioprocessing of organic-bearing process waste streams, both liquid and vaporous, is also an important consideration. ${ }^{13,26}$ By its very nature, bioprocessing of petroleum or petroleum products must deal with nonaqueous media. Serious consideration is being given to the biological removal of sulfur, nitrogen, and heavy metals, as well as to enhancing the physical properties of petroleum. ${ }^{24,25}$ Subsequent bioprocessing of liquid and vaporous process waste streams from petroleum processing has also been considered. ${ }^{13,18,26}$

Biological concepts can be considered for natural gas processing, particularly in conducting the various required scrubbing operations. There is also the possibility of bioprocessing of liquefied natural gas and other liquefied 
hydrocarbon gases, especially for the removal of heteroatoms and other hazardous components.

A nonaqueous bioprocessing application that is currently being studied is the use of microorganisms to enhance the recovery of crude oil from exhausted reservoirs. ${ }^{27}$ Similarly, microbial systems may be able to interact with the structures that tie up the hydrocarbons in oil shale and tar sands, thus assisting in the recovery of the included oil.

\subsection{CONVERSION OF RENEWABLE FEEDSTOCKS}

A primary thrust in bioprocessing development for energy applications in recent years has been the conversion of renewable feedstocks to fuels or chemicals. ${ }^{1-6}$ Substantial quantities of these materials are already being produced by bioprocessing systems, and there appears to be a growing industrial interest in further expansion. The potential market for biologically produced ethanol, other fuel enhancers, neutral solvents, and organic acids could require greater than 100 million tons of additional biomass per year. ${ }^{28.29}$

Although most bioprocess development to date has not utilized nonaqueous processing for these applications, several potential areas exist where nonaqueous systems could be helpful. These potential applications include bioconversion processes in which there is a simultaneous separation step utilizing a liquid organic extractant; ${ }^{30}$ biomass pretreatment or combined pretreatment and bioconversion in which organic liquids or supercritical $\mathrm{CO}_{2}$ is used; or subsequent bioprocessing for upgrading some of the concentrated products of the conversion of renewable feedstocks.

\subsection{ORGANIC SYNTHESIS}

Until relatively recent times, it was thought that biocatalysts would have little utility for large-scale organic syntheses, since a liquid organic reaction medium is usually required for such processes and biocatalysts were thought to be inactive in contact with organics. We now know that many biocatalysts, 
especially enzymes, can be effectively used in some types of organic liquids and, in some cases, with the total absence of water. ${ }^{31}$ This is important, since the thermodynamic equilibrium of many synthesis processes, such as the production of esters from carboxylic acids and alcohols or of peptides from amino acids, is unfavorable in water.

In organic synthesis, there is a great advantage in using catalysts that have significant specificity for the product of interest rather than for by-product formation so that costly separation, purification, and waste treatment is reduced. ${ }^{31,32}$ In general, biocatalysts do have such specificity, which may even be enhanced in organic media. Such biocatalysts can also be used under mild operating conditions.

It has been estimated that over $95 \%$ of the products of the organic chemical industry could be produced with bioprocesses. ${ }^{28.29}$ This would represent a production of more than $\$ 100 B / y e a r$ of commodity products.

\subsection{ENVIRONMENTAL CONTROL TECHNOLOGY}

Bioprocessing systems may be especially well suited for the treatment of hazardous wastes with high specificity and energy economy. ${ }^{24,33,34}$ Many of the future processing requirements in this field are driven by federal and state regulations that can be especially severe for some energy production areas. Process-derived effluents and residues must be accommodated, and the environmental restoration of severely contaminated sites must also be addressed. $^{3}$

Biodegradation of organic chemical pollutants in both liquid and gaseous effluents is becoming a preferred treatment technology for the removal of hazardous chemicals. Nonaqueous bioprocesses could include treatment of the organic components of a liquid effluent in a second dispersed phase and treatment of hydrocarbon gases or vapors present in an effluent gas stream. Various bioprocessing approaches are being considered for treatment of both types of effluents. ${ }^{18,19,35}$ 
Biological treatment of contaminated sites is receiving an increasing amount of attention. ${ }^{34,36,37}$ Of particular relevance to nonaqueous bioprocessing is the microbial degradation of hydrocarbon liquids that are frequently found in contaminated soils and of the hydrocarbon vapors and gases that result from venting and bioventing techniques that are being investigated for cleanup. ${ }^{3638}$ 


\section{NONAQUEOUS BIOPROCESSING: AN OVERVIEW AND STATUS}

Although nonaqueous bioprocessing has been postulated for some time, there is a recent increase in both interest and preliminary research activity in bioprocessing systems associated with the biocatalysis of essentially hydrophobic compounds that are present in a nonaqueous medium. The substrate can be liquid, gaseous, or solid, and the reaction medium can be either liquid or gaseous. To date, organic liquids have been the most common nonaqueous media investigated for bioprocessing, although supercritical fluids and some gases have also been examined. Both microorganisms and isolated enzymes can be considered as the biocatalyst in these types of bioconversion processes, but catalytic antibodies and other functional proteins may ultimately be useful as well.

\subsection{THE BIOPROCESSING SYSTEM}

Although the bioconversion step will be the focal point of nonaqueous bioprocessing, the impact on the rest of the processing system must also be considered. In some cases, there will also have to be special considerations for feed preparation, biocatalyst formulation, and downstream processing for an integrated nonaqueous bioprocessing system (Fig. 1). Monitoring and controls could also have special requirements. There has been some consideration of all of these processing components for various types of nonaqueous biocatalytic systems, with most attention focused on organic liquid media and gaseous systems. ${ }^{15,16,18}$ But, even for these types of bioprocesses, little attention has been given to integrated systems in which all aspects of the bioprocess are addressed. 


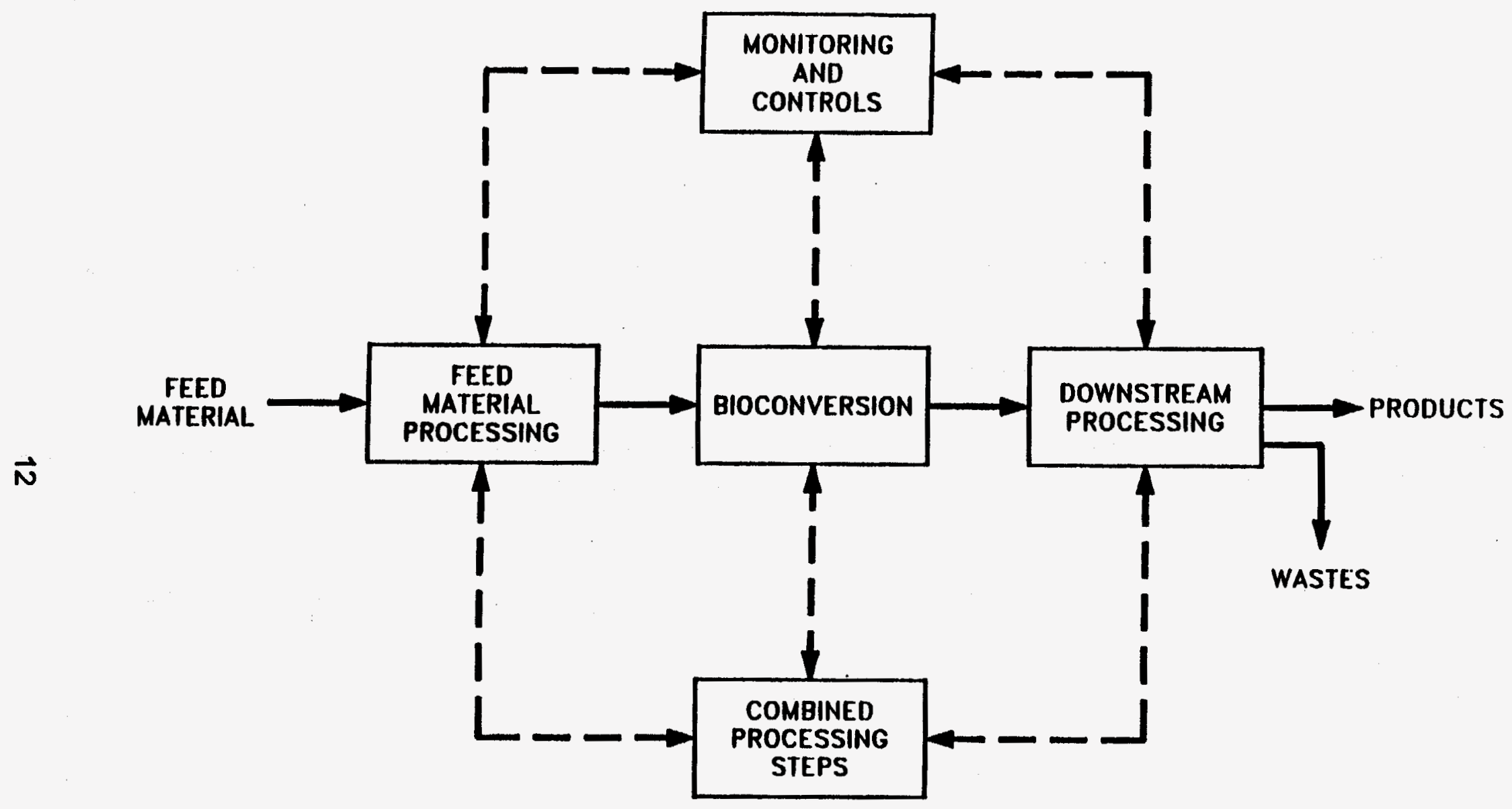

Fig. 1. The components of an integrated bioprocessing system. 


\subsection{BIOCATALYSIS IN ORGANIC LIQUIDS}

It has now been shown that biocatalytic processing may have a wide range of applicability for liquid organic media, especially water-immiscible solvents. ${ }^{1417}$ At least four types of reaction systems contain a water-immiscible organic liquid (Fig. 2). Three of these utilize a dispersion of either the organic or aqueous phase in an aqueous or organic phase, respectively, with the biocatalyst being in the aqueous phase but with interfacial contact with the organic phase. In such systems, the biocatalyst may be present in the aqueous phase as particulates (suspended microorganisms or immobilized into or onto solid particles) or as dissolved enzymes. For such bioprocesses to be effective, the biocatalysts must be stable and active in contact with the organic phase. Also, the bioreactor concept used should effectively furnish contact between the two phases and provide for phase disengagement while providing continuous operation. A fourth processing approach occurs when the biocatalyst (typically an isolated enzyme) is present in the organic liquid as a particulate in the absence of water or perhaps as a dissolved biocatalytic molecule after chemical modification.

Biocatalysts such as microorganisms or isolated enzymes can be effective in various aqueous environments, and they will be the catalytic agent in any system in which there is interaction at an aqueous-organic interface. Some microorganisms, such as microbial contaminants of fuel tanks and those found at the sites of marine or terrestrial oil spills, ${ }^{39}$ are known to inhabit largely nonaqueous and/or biphasic environments. These biocatalysts have been shown to conduct potentially useful metabolic activities in situ. Also, it is known that some enzymes are immobilized in vivo within cell membranes, which are themselves relatively hydrophobic environments. In many cases, the enzymes are actually within the lipid bilayer of the cell membrane. Enzymes of this type may be isolated from a wide variety of organisms, suggesting that enzymatic catalysis in largely nonaqueous intracellular environments is a widespread phenomenon. Preliminary investigations have been carried out on several 
ORNL DWG $94 A-110$

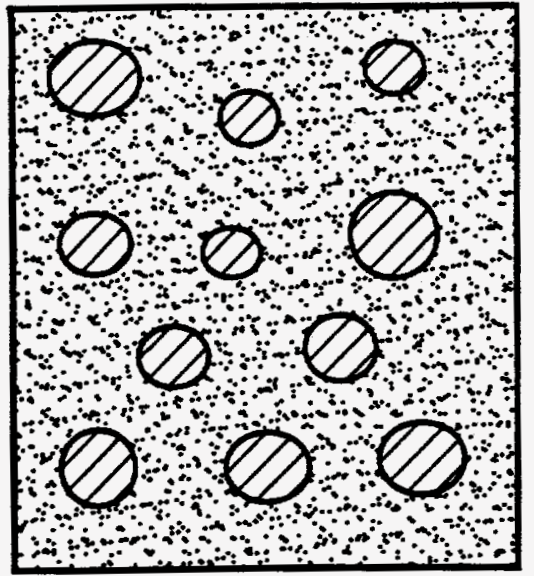

Organic Dispersed in Aqueous with Soluble Biocatalyst

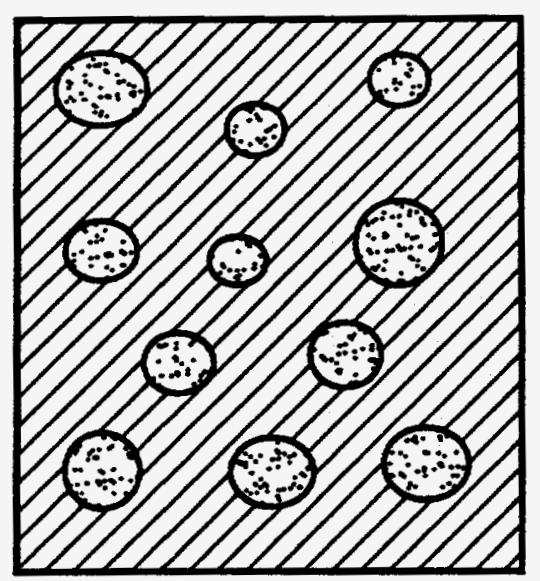

Aqueous with Soluble Biocatalyst Dispersed in Organic

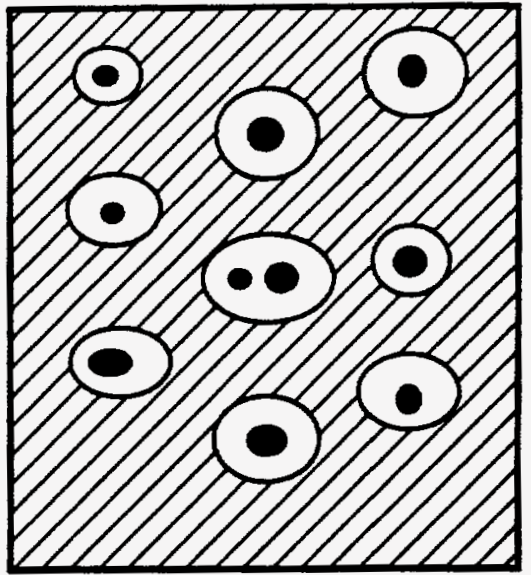

Aqueous with Insoluble Biocatalyst Dispersed in Organic

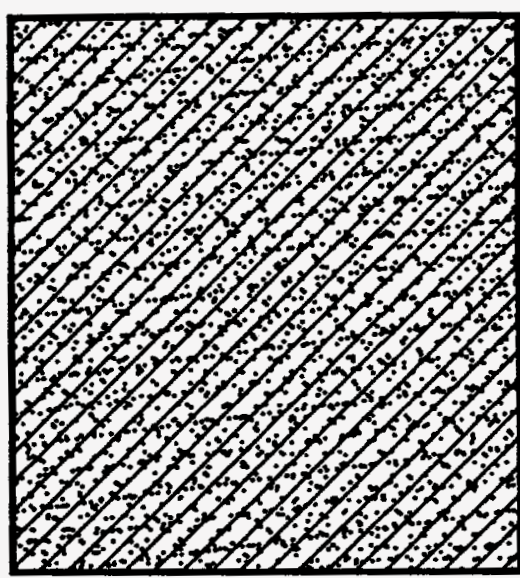

Organic with Soluble or Particulate Biocatalyst

\section{$\square$ Aqueous $\quad$ Soluble Biocatalyst \\ VIA Organic Insoluble Biocatalyst}

Fig. 2. Some possible biocatalytic systems involving an organic liquid. 
different biocatalysts with a variety of organic phases. Some of these reactions are characterized in Table 1. In almost all cases, a complete understanding of the actual biological process is missing, and little progress has been made toward advanced bioreactor systems and other processing techniques.

\subsubsection{Effects of Organic Solvents}

Enzyme or microbial deactivation may occur in some two-phase systems, presumably by either the action of a toxic organic substance, especially when the organic has high solubility in the aqueous phase, or by the potential deleterious effects of liquid-liquid interfaces on the structure of the biocatalyst. ${ }^{5961}$ Research with extractive fermentation has shown that the toxicity of various solvents may depend on both the solvent and on the cell type. ${ }^{59.60,62}$

Biocatalysts have also been used in water-miscible organic solvents or in aqueous-organic mixtures of such solvents. In general, these more hydrophilic organics have a much greater detrimental effect on biocatalysts, although some recent research suggests that proper species selection or mutation can alleviate some of this problem.

Cells inhibited in the presence of an organic phase may be at least partially protected by immobilization or by the use of membranes. ${ }^{65}$ The actual cause of inhibition by organic liquids is not well understood, although with microorganisms it could be associated with destabilization of the microbial membrane. On the other hand, enzymes may be denatured as a consequence of conformational changes that result in a loss of activity. This phenomenon appears to be related to the protein-solvent interaction and/or to the removal of water and dehydration of enzyme protein.

Considerable disagreement remains on the effects of the organic medium on enzyme activity. ${ }^{15.16 .00}$ Some of this is due, in part, to the broad range of enzymes that are being screened for use in this type of environment as well as to conflicting experimental results. The nature of the solvent, particularly its hydrophobicity, and the water content of the solvent seem to be important. ${ }^{67-73}$ It 
Table 1. Examples of some biocatalytic reactions

observed in aqueous/organic systems

$\begin{array}{lll}\text { Reaction Catalyst } & \text { Solvent } & \text { Reference }\end{array}$

Reactions in One-Phase Mixtures of Water and Organic Solvents

$\begin{array}{ll}\text { protein hydrolysis } & \text { typsin } \\ \mathrm{H}_{2} \mathrm{O}_{2} \text { production } & \text { alcohol oxidase } \\ \text { transesterification } & \text { lipase } \\ \text { hydrogenation } & \text { hydrogenase } \\ \text { triglyceride esterification } & \text { lipase } \\ \text { anisidine oxidation } & \text { peroxidase } \\ \text { cellulose hydrolysis } & \text { cellulase }\end{array}$

sucrose polyester synthesis protease

$\begin{array}{ll}\text { benzene } & 40 \\ \text { kerosene mixtures } & 41 \\ \text { various } & 14 \\ \text { various } & 42 \\ \text { cyclohexane } & 43 \\ \text { toluene } & 44 \\ \text { toluene, } & 45 \\ \text { dimethylformamide, } & \\ \text { acetone, etc. } & \\ \text { pyridine } & 46\end{array}$

Iwo-Phase Liquid-Liquid Systems with Water and Organic Solvent

cholesterol oxidation

phenol polymerization

amino acid esterification reduction of organic compounds peptide synthesis lignin depolymerization

quinone oxidation amino acid esterification

aldehyde synthesis

naphthalene hydroxylation hydrocarbon degradation arene oxidation steroid oxidations cholesterol oxidase

peroxidase

chymotrypsin

alcohol dehydrogenase papain peroxidase

peroxidase chymotrypsin

alcohol dehydrogenase immobilized NAD microbes Anthrobacter sp. alcohol oxidase cholesterol oxidase toluene, cyclohexane, carbon tetrachloride, benzene dimethylformamide, dioxane ethanol

heptane

trichloroethylene

dioxane, dimethylformamide chloroform

benzene,

butanol,

butylacetate

hexane

various

heptamethyinonane

hexane

hexane/isopropanol

\section{0}

9

.


may be possible to partially protect some biocatalysts from denaturation by maintaining them within an aqueous microenvironment by use of reversed micelles ${ }^{74,75}$ or aqueous complexation ${ }^{76,77}$ or by immobilizing the biocatalyst into a porous solid matrix that also contains water. ${ }^{53.54}$

\subsubsection{Effects of Interfaces}

Many enzymes, and probably all microorganisms used as catalysts with organic liquids, will display higher performance if contained in an aqueous phase. Thus, for many bioprocesses using these solvents, a two-phase system with both aqueous and organic phases will be required. Both enzymatic and microbial catalysts may be affected by exposure to interfaces between the two phases. Enzyme denaturation at interfaces is presumably due to (1) dehydration of parts of the adsorbing protein, (2) double-layer overlap leading to a redistribution of charged groups, or (3) structural rearrangements in the adsorbing protein. Actual effects of interfaces on the stability of microbial catalysts are not well known, but enzymes, like virtually all proteins, are surfactant molecules, and when aqueous solutions of proteins are contacted with another liquid phase, they tend to accumulate at the interface. ${ }^{78.79}$

There are conflicting reports on whether an interface is directly inhibitory to microbes. ${ }^{81}$ It may be that the changes in component concentrations near the interface are responsible for observed changes in activity; but, to date, no conclusive evidence has been found that interfaces cause a structural change in microbial catalysts. ${ }^{78}$ The question of protein adsorption and desorption at gasliquid interfaces has received some attention, ${ }^{79}$ but there has been little experimental investigation of the effects of liquid-liquid interfaces. Interfacial adsorption would be expected to depend on the nature of the particular enzyme/solvent system. For example, small enzymes and those that deviate significantly from a spherical shape have large surface-to-volume ratios, and thus a large fraction of their hydrophobic residues could be exposed to the surface. Hence, there is a relatively uniform distribution of polar and apolar species over 
the enzyme surface, and hydrophobic patches on the surface are generally absent. These may be considered as "hard" enzymes in the sense that little change in structure would be expected to occur upon contact with the liquid interface because there are no large hydrophobic regions on the protein surface. In contrast, large globular enzymes with a significant degree of surface hydrophobic patches are "soft," because they may undergo a rearrangement in protein structure upon adsorption. Therefore, activity may be retained upon adsorption at a liquid-liquid interface by small enzymes that are "hard," whereas larger ones may undergo conformational changes that may reduce or eliminate catalytic activity. Additional work will be required to properly understand these phenomena.

\subsubsection{Chemical Modification of Biocatalysts}

Enzymes have limited solubility in organic liquids, especially in those that are relatively hydrophobic. However, it has been shown that some enzymes can be chemically modified so that they may be solubilized in organic solvents. The approach taken by some researchers is to increase the hydrophobicity of these proteinaceous materials by chemical modification. For example, poly(ethylene glycol) derivatives of enzymes have increased organic solubility. ${ }^{42,80,81}$ Other lipophilic chemical moieties, such as dinitrophenyl groups, have also been added to enzyme molecules to increase solubility in organic liquids. ${ }^{22}$ In almost all cases, such chemical modifications also reduce the enzyme activity. So, there has to be a balance between increasing solubility in organic liquids and the potential loss of catalytic activity.

Microbial cell hydrophobicity is affected by physiological state and/or growth conditions and can be enhanced by treatment of the cell with polycations such as chitosan, polylysine, or lysozyme. ${ }^{82}$ In the latter case, enhanced hydrophobicity is probably caused by a combination of surfactant effects related to coating of the cell with a hydrophobic layer and neutralization of the cell's inherent negative surface charge. In general, without such modifications, and 
usually even with these modifications, biocatalyst activity in the organic phase appears to be lower than in the aqueous phase. Overall, research on the chemical modification of biocatalysts to enhance interaction in organic liquids has been very preliminary in nature, and the effects on biocatalytic mechanisms have not been well established.

\subsubsection{Biocatalyst Engineering}

The ability to use enzymes in vitro in nonnatural environments (i.e., in organic liquids) expands their potential applications, particularly in the area of chemical conversion processes. However, nature does not necessarily optimize proteins for such in vitro applications especially where the conditions differ substantially from the enzyme's natural surroundings. Alternatively, the basic structure of enzymes could be modified by site-directed mutagenesis (protein engineering) $)^{83,84}$ or even random mutagenesis coupled with screening or selection. ${ }^{63,64}$ These approaches are beginning to be investigated for producing enzymes that will be more compatible with the organic environment. The most encouraging results appear to be with microorganisms or enzymes from microorganisms that have appreciable catalytic activity even when exposed to high concentrations of relatively hydrophilic organic solvents. ${ }^{63,64}$ it has also been shown that sometimes proteins can be further stabilized by the addition of metal chelation sites into their structure. ${ }^{85}$ This approach may also have applications in the use of enzymes in contact with organic media.

\subsubsection{Advanced Bioreactor Concepts}

Although there appears to be many potentially beneficial biocatalyzed reactions in contact with an organic phase, there has been only limited work on the investigation of the potential reactor systems and operating parameters. Thus, information on the more fundamental kinetic and transport mechanisms in such reactor environments is sparse. What is needed is an understanding of interphase contact and transport and the effects of system parameters on the 
intrinsic biocatalytic kinetics so that an optimum configuration for such reactor systems can be developed. 61.86

Immobilized biocatalysts can potentially be used in fixed-bed or fluidizedbed bioreactors or even in a stirred tank with a continuous organic phase..$^{53,54,86,87}$ Limited interfacial area will be available in such systems, and it may be difficult to replenish the necessary aqueous component needed for activating or regenerating the bioreagent. Such columnar bioreactor concepts do provide for excellent phase disengagement and, for some applications, they should be amenable to continuous operation. However, a better understanding of interphase mass transport and biocatalyst replenishment is needed.

An alternative, and perhaps more generally useful approach, would require the development of reaction systems that would provide effective contact between the biocatalyst, contained within an aqueous phase, and the organic phase. Similar requirements are also needed for efficient liquid-liquid extraction systems, so techniques developed for those applications may also be useful for advanced bioreactor concepts. High interfacial areas between the two phases are required for maximizing mass transport; therefore, one of the phases must be efficiently dispersed in the other phase in order to enhance reactivity. There must also be an effective technique for phase disengagement.

The addition of a surfactant to such systems can affect interfacial area and presents another variable that can be utilized in interphase dispersion. For example, depending on surfactant concentration, this allows the use of micelles, reverse micelles, or liquid crystal systems. ${ }^{74,75,88}$ In those approaches, an extra processing step is required in which there must be the addition of a reagent to break the dispersion. When low surfactant concentration (or no surfactant) and high water concentration are used, mechanical or electrical dispersion of one phase in the other and subsequent coalescence can be carried out without the introduction of additional reagents. If the dispersed droplets are small enough, the resulting emulsion-phase bioreactor system should be very effective. 
In a liquid-liquid contacting system, the overall rate of substrate conversion will depend on process conditions such as amount of surface area, substrate concentration, hydrodynamics, and reaction kinetics. ${ }^{4}$ Several mass transfer studies have been performed for molecules of interest to bioreactions including the use of surfactants. ${ }^{89}$ in general, it has been found that highsurface-area concepts (emulsions) are most effective in reducing mass transfer effects.

The primary issue then becomes control of the hydrodynamic state of the multiphase liquid system. This control involves not only creation of significant amounts of interfacial surface area but also phase coalescence/disengagement and regulation of the two-phase liquid flow. As indicated above, use of surfactants allows the use of microemulsions. But liquid-liquid emulsions can also be produced by mechanical means and by the recently developed use of external electrical fields. ${ }^{90,91}$ In the latter case, the electric field also contributes to coalescence, thus allowing a single contacting device that operates continuously with the possibility of multistage operation by use of a columnartype system. This preliminary information on a variety of approaches is very interesting, but a definitive data base has to be developed before reasonable choices can be made.

\subsection{BIOCATALYSIS IN ORGANIC GASES}

It is well known that many biocatalysts, both microorganisms and enzymes, can interact with various organic gases and vapors. ${ }^{18,19,36-39,92-94}$ In some cases, these biocatalysts can maintain significant activity in the gas phase where there is very little water present. Although research in this area has not been extensive, some bioprocessing systems are under development, especially in the area of environmental control technology. ${ }^{18,19}$ Unfortunately, definitive research on other possible biocatalytic systems and on advanced bioreactor concepts is very scarce. As a result, process development must be empirical in 
nature. A scientific and engineering understanding that would allow a more rational approach would be most useful.

\subsubsection{Biocatalytic Systems}

Mixed-culture microbial systems ${ }^{18,19}$ and a few specific oxidative enzyme systems $s^{92-94}$ have been investigated for gas-phase processing, at least with preliminary experimentation. However, more comprehensive testing and a wider range of bioconversion concepts will be critical in expanding the use of this type of technology. This will include those bioconversion processes that require an anaerobic environment and that can operate at high temperatures. The effects of gaseous hydrocarbons and other gaseous constituents on the biocatalytic activity must be established, and the effects of humidification, or lack thereof, must also be determined.

\subsubsection{Advanced Bioreactor Concepts}

To date, most bioreactor concepts for gas-phase systems have included some means of immobilizing the biocatalysts into or onto solid support materials that are then enclosed in a bioreactor. ${ }^{18.19}$ In situ bioremediation where microorganisms in the soil are used to degrade organic vapors or the use of socalled biofilters would represent a subset of this type of system. ${ }^{33,34.37}$

Some means of maintaining biocatalytic activity must be coupled with the immobilized biocatalyst, such as by using a discontinuous aqueous phase in a trickle-bed. ${ }^{19}$ Columnar systems in which there is a continuous aqueous phase and either fixed-bed or fluidized-bed operation and a dispersed gas phase should also be considered. Continuous, columnar systems will probably be the bioreactor concept of choice, but the kinetics and hydrodynamics of such threephase systems must be understood and predictable. 


\subsection{BIOCATALYSIS IN SUPERCRITICAL FLUID SYSTEMS}

Supercritical fluids (materials above their critical temperature and pressure) also represent a class of nonaqueous media with many features which make their use as solvents or dispersents for biocatalysis particularly desirable. That is, they have densities comparable to liquids with resulting enhanced solvation, but with transport properties comparable to those of gases. Although there is much less information on the use of supercritical fluids for biocatalysis compared to that on the use of organic solvents, there is increasing interest in this type of bioprocessing. ${ }^{20,21,92.95,96}$

To date, most work has been carried out with supercritical $\mathrm{CO}_{2}$ that can effectively operate at moderate temperatures (critical temperature is $31.1^{\circ} \mathrm{C}$ ), where biocatalysts should maintain activity. However, other inorganic and organic materials have also been investigated as supercritical fluids for biocatalysis. ${ }^{96}$ Additional advantages of supercritical $\mathrm{CO}_{2}$ are that it is relatively nontoxic, and, as in all supercritical fluids, transport properties are enhanced over those in the liquid phase. It has even been reported that some biocatalyzed reactions are faster in supercritical fluids than they are in organic liquids. ${ }^{96}$ Also, many potential substrates for enzyme conversion have reasonable solubilities in supercritical fluids. Finally, products, substrates, and the biocatalysts can usually be recovered by depressurization and temperature change.

\subsubsection{Biocatalytic Systems}

Most of the research to date has used enzymes in supercritical $\mathrm{CO}_{2}$, sometimes with small quantities of water and other cosolvents. ${ }^{20,21,92,95-98}$ There has also been limited work with other supercritical fluids such as fluoroform, ethylene, propane, sulfur hexafluoride, and ethane. ${ }^{96-88}$ At least with $\mathrm{CO}_{2}$ and the limited number of other supercritical fluids and biocatalysts tested, enzymes in such systems are apparently present as particulates with no measurable solubility. ${ }^{98}$ Supercritical fluids offer the flexibility of changing the physical properties of the system without changing the solvent and without causing 
apparent changes in the enzyme structure and activity. This can be achieved in a predictable, continuous, and controllable fashion simply by varying the pressure or temperature of the system. ${ }^{98}$ Enzyme activity can be lost during depressurization, presumably owing to the rapid release of the fluid from the bound water around the protein. Also, there is some indication that pressures much greater than the supercritical pressure for $\mathrm{CO}_{2}$ can adversely affect activity. ${ }^{97,98}$ Various cosolvents, such as some alcohols, can increase the solubility of organic substances in supercritical $\mathrm{CO}_{2}$. However, such systems have not been carefully evaluated for their effects on various enzymes.

The number of different enzymes that have been investigated with supercritical fluids is much less than those which have been studied with organic solvents. Thus, generalities have been more difficult to established. Also, microbial biocatalysts, even nonliving systems, have not been seriously studied in supercritical fluids, nor has there been extensive experimentation on systems other than $\mathrm{CO}_{2}$.

\subsubsection{Advanced Bioreactor Concepts}

Supercritical fluid extraction systems have been used commercially, so the bioreactor systems used so far have been based on those concepts. There has been little development of new approaches that are more directed toward biocatalytic systems, especially for multiphase systems such as supercritical fluids in contact with immobilized biocatalysts. Much work remains to be done in this area, especially with concepts that are compatible with continuous operation. 


\section{RESEARCH AND DEVELOPMENT NEEDS AND OPPORTUNITIES}

Bioprocessing in nonaqueous environments represents an innovative approach that could have an important impact on energy-related applications. Although there is increasing academic and industrial interest, this evolving bioprocessing area is still not well understood, and the necessary biochemical and engineering principles have not been sufficiently well established to allow enlightened process development, design, and scaleup. This alternative approach to bioprocessing could result in a whole new class of processing options that are more economic, require less energy, and are environmentally benign, provided that adequate research and development is carried out to establish the necessary understanding and data base. A whole new industry could well be in the making.

The most effective nonaqueous bioprocessing concepts will utilize enhanced biocatalysts, in advanced bioreactors, operating under optimum conditions, that are well integrated into the total bioprocessing system including upstream and downstream processing. Research needs and opportunities in these areas will be further discussed in the context of a relatively general or generic approach, but with the understanding that each of the different types of nonaqueous media will impose its own restrictions on the investigations.

\subsection{ENHANCED BIOCATALYSTS}

Up to this time, most of the research in nonaqueous bioprocessing has been carried out with a few enzymes and microorganisms that are readily available and relatively well characterized by previous use in aqueous media. However, there are literally thousands more such biocatalysts that are potentially available from natural sources. Also, there is the potential for isolating or restructuring biocatalysts by nonnatural means that might result in bioreagents that are even more compatible with nonaqueous systems. This area of 
bioprocessing research will be one of the most critical for future bioprocess development.

It will be particularly appropriate to study additional biocatalysts that also have been characterized for other aqueous bioprocesses as well as search for additional naturally derived materials. In the latter case, scouting tests should include nonaqueous media in the screening process. To date, reducing systems have received minimal attention, but they also should be evaluated since there are many potential industrial uses for such biocatalysts.

Entirely different types of biocatalysts that are more compatible with nonaqueous media should also be developed and studied. This should certainly include the use of protein engineering (both site-directed and random mutagenesis) of enzymes; the chemical modification of such biocatalysts; and entirely new approaches, such as the formulation of catalytic antibodies and other functional proteins. In addition, the reasons for reduced biocatalytic activity in organic solvents, compared to that in water, need to be elucidated and incorporated into rational stabilization strategies.

\subsection{EFFECTS OF OPERATING ENVIRONMENT ON THE BIOCATALYST}

Biocatalysts in nonaqueous media are susceptible to the same environmental factors that are present in aqueous media. Thus, conditions such as optimum temperature, pressure, substrate concentration, and $\mathrm{pH}$, will have to be determined for each potential bioprocessing concept. Nonaqueous media may also affect biocatalytic kinetics, and these effects will have to be understood and predictable in order to design and scaleup commercial-size equipment. In addition, nonaqueous bioprocessing offers a novel option of controlling biocatalytic behavior (activity, selectivity, stability, etc.) by choice of one medium over another.

Some of these effects will be generic in nature and, thus, could be studied in a general sense. This is especially true for the effects of different types of solvents, substrates, and interfaces on both microorganisms and enzymes. Of 
particular interest will be the effects on enzyme structure and biocatalytic mechanisms for all of the possible nonaqueous media: organic liquids, organic gases, and supercritical fluids.

\subsection{ADVANCED BIOREACTOR CONCEPTS}

Improved biocatalysts cannot be fully exploited in a bioprocess without an efficient bioreactor system that optimizes the operating environment, enhances operability, and reduces the effects of mass transport resistance. Some of the same advanced bioreactor concepts developed for aqueous media will be useful for nonaqueous processing, but the nonaqueous environment imposes additional restrictions and requirements on bioreactor configuration and mode of operation.

It is expected that some approaches will require the biocatalyst to be immobilized (e.g., for fixed-bed or fluidized-bed applications in multiphase systems). Many of the previously developed immobilization techniques will be applicable here, ${ }^{99-101}$ with the understanding that additional research will be required to evaluate the effects of the nonaqueous media.

In concepts where a dispersion of one liquid phase in another is required, previous work, primarily in the separations area (e.g., liquid-liquid solvent extraction and the use of micelles and reversed micelles), will be the beginning point for the development of advanced bioreactors. The interaction of the biocatalyst in one of the phases gives an added complexity that must be thoroughly studied, and the increasing interest in continuous operation will require additional complexity. More efficient means will be required for interphase dispersion followed by coalescence in multistage bioreactors.

Applications to gas-phase bioprocessing will also require innovative bioreactor systems. Advanced concepts will be required for gas-phase continuous and liquid-phase-continuous systems with the capability for either immobilized or circulating biocatalysts.

To date most testing of biologically catalyzed reactions in supercritical fluids has been done with bioreactor configurations that have been adapted from 
those techniques used for supercritical extraction systems. ${ }^{95-98}$ Additional research will be required to optimize these approaches and to ensure continuous operations. The addition of the biocatalyst, perhaps in an immobilized form, will also require innovative new concepts for efficient operation.

In order to provide a basis for design and scaleup, predictive mathematical models represent the most effective approach. The development of these models should be based on the various biochemical and engineering mechanisms in the reactor system rather than on gross empiricisms.

\subsection{THE BIOPROCESSING SYSTEM}

In some cases, both upstream and downstream processing for bioprocesses utilizing nonaqueous media will require techniques different from those used in the more conventional aqueous systems. This will require investigation of procedures for incorporating the substrate in a nonaqueous media as well as the recovery of the products, residual substrates, and even the biocatalysts from nonaqueous and as well as aqueous media. Additional processing steps may be required for breaking up microemulsions and recovering materials, especially relatively volatile products and substrates, from supercritical fluids.

There will also be the need for new approaches to process monitoring and control. This will be particularly true for bioprocesses utilizing supercritical fluids and liquid-liquid emulsions. 


\section{SUPPORT FOR RESEARCH AND DEVELOPMENT}

There is increasing interest in nonaqueous bioprocessing by various universities, government laboratories, and industries. Support for research and development in this evolving area is slowly increasing. It is becoming obvious, however, that this new R\&D area has matured to the extent that a greater increase in research and development would result in rapid bioprocess development and industrial implementation of many new and exciting concepts. There is the potential to initiate a whole new bioprocessing industry for chemicals and fuels and for environmental control technology.

Governmental support has been the primary driving force in this evolving field. In the United States, this has primarily been accomplished through the National Science Foundation (NSF), the Department of Energy (DOE), and the Department of Defense (DOD). The NSF has provided limited support in the more fundamental areas, while DOE and DOD have supported a small amount of fundamental research (e.g., DOE's Office of Basic Energy Sciences) with a growing interest in applications. Within DOE, this has been especially true in the fossil energy area (Office of Fossil Energy) and in contributions to a more efficient chemical industry (Office of Industrial Technologies).

These efforts need to be expanded, and there should also be additional support for "bridging" research and development (perhaps in the DOE Office of Industrial Technologies) that would establish the necessary technology base which would allow for a variety of bioprocess developments. Such an effort could effectively start at about a $\$ 5 \mathrm{M}$ level and expand to $\sim \$ 10 \mathrm{M}$ over a 3-year period. It would be expected that such R\&D would be supported at national laboratories and in academia with the anticipation that there would be additional cooperative industrial R\&D as the technology matures. 


\section{REFERENCES}

1. Humphrey, A. C., "Commercializing Biotechnology: Challenge to the Chemical Engineer," Chem. Eng. Prog. 80(4), 7 (1984).

2. Amundson, N. R., et al., Frontiers in Chemical Engineering - Research Needs and Opportunities, pp. 18-35, National Academy Press, Washington, D.C. (1988).

3. Scott, C. D., Gaden, E. L., Humphrey, A. E., Carta, G., and Kirwan, D. J., Bioprocessing Research for Energy Applications, U. S. Department of Energy Report, ORNLTM-11054, 1989.

4. Scott, C. D., "Bioprocessing Research for Energy Applications: Needs and Opportunities," Biotechnol. Prog. 5(2), J3-J5 (1989).

5. Ladisch, M. R., et al., Putting Biotechnology to Work - Bioprocess Engineering, pp. 1-120, National Academy Press, Washington, D.C. (1992).

6. FCCSET (Federal Coordinating Council for Science, Engineering, and Technology), Biotechnology for the 21st Century, pp. 1-29, A Report by the FCCSET Committee on Life Sciences and Health, Office of Science and Technology Policy, Executive Office of the President, Washington D.C. (1992).

7. Hartdegen, F. J., Coburn, J. M., and Roberts, R. L., "Microbial Desulfurization of Petroleum," Chem. Eng. Prog. 80(5), 63-7 (1984).

8. Lee, D. D., and Scott, C. D., Impact of Biotechnology on Coal Processing, U. S. Department of Energy Report, ORNL-6459, 1988.

9. Beecy, D. J., et al., Advanced Research Program Plan - Crosscutting Fossil Fuels Science and Technology, pp. A5.1-A5.8, U. S. Department of Energy Report, DOE/FE-0250T, 1992.

10. Hall, D. O., and Overend, R. P., Eds., Biomass: Regenerable Energy, pp. 1-504, John Wiley \& Sons, New York (1987).

11. Martin, A. M., Ed., Bioconversion of Waste Materials to Industrial Products, pp. 1-510, Elsevier, London (1991). 
12. Walker, J. F., Hancher, C. W., Genung, R. K., Patton, B. D., Kowalchuk, M., "Biological Treatment of Nitrate Wastewater Using Fluidized-Bed Bioreactors," Biotechnol. Bioeng. Symp. 11, 415-27 (1981).

13. Lee, D. D., Scott, C. D., Hancher, C. W., "Fluidized-bed Bioreactor of Coal-Conversion Effluents," J. WPCF 51, 974-84 (1979).

14. Zaks, A., and Klibanov, A. M., "Enzyme-catalyzed Processes in Organic Solvents," Proc. Natl. Acad. Sci. U.S.A. 82, 3192-96 (1985).

15. Tramper, J., van der Plas, H. C., and Linko, P., Eds., Biocatalysts in Organic Synthesis (Proceedings of an International Symposium on this Subject), pp. 1-259, Elsevier, Amsterdam, (1985).

16. Laane, C., Tramper, J., and Lilly, M. D., Eds, Biocatalysis in Organic Media (Proceedings of an International Symposium on this Subject), pp. 1-426, Elsevier, Amsterdam, (1987).

17. Dordick, J. C., "Enzymatic Catalysis in Monophasic Organic Solvents," Enzyme. Microb. Technol. 11, 194-211 (1989).

18. Bohn, J. L., "Consider Biofiltration for Decontaminating Gases," Chem. Eng. Prog. 88, 34-40 (1992).

19. Davison, B. H., and Thompson, J. E., "The Removal of Alkanes in a Liquid-Continuous Gas-phase Bioreactor: Preliminary Considerations," Appl. Biochem. Biotechnol. 45/46, 917-23 (1994).

20. Randolph, T. W., Blanch, H. W., Prausnitz, J. M., and Wilke, C. R., "Enzymatic Catalysis in a Supercritical fluid," Biotechnol. Lett. 7, 325-28 (1985).

21. Russell, A. J., and Bechman, B. J., "Enzymes in Supercritical Fluids," Appl. Biochem. Biotechnol. 31, 197-211 (1991).

22. Scott, C. D., Woodward, C. A., and Scott, T. C., "Use of Chemically Modified Enzymes in Organic Solvents for Conversion of Coal to Liquids," Catal. Today 19, 381-94 (1994).

23. Kaufman, E. N., and Scott, C. D., "Liquefy Coal with Enzyme Catalysts," ChemTech 24(4), 27-32 (1994).

24. Finnerty, W. R., "Microbial Desulfurization of Fossil Fuels: A Review," Biotechnol. Bioeng. Symp. 16, 205-21 (1986). 
25. Faison, B. D., et al., "Degradation of Organic Sulfur Compounds by a Coal-Solubilizing Fungus." Appl. Biochem. Biotechnol. 28/29, 237-51 (1991).

26. Leson, G., and Winer, A. M., "Biofiltration: An Innovative Air Pollution Control Technology for VOC Emissions," J. Air Waste Manage. Assoc. 41, 1045-54 (1991).

27. Watson, J. S., and Scott, C. D., The Impact of Bioprocessing on Enhanced Oil Recovery, U. S. Department of Energy Report, ORNLTM-10676, Oak Ridge, TN, 1988.

28. Busche, R. M., "The Biomass Alternative - A National Insurance Policy to Protect the US Strategic Supply of Chemical Feedstocks," Appl. Biochem. Biotechnol. 20/21, 655-74 (1989).

29. Leeper, S. A., Ward, T. E., and Andrews, F. F., Production of Organic Chemicals via Bioconversion: A Review of the Potential, U. S. Department of Energy Report, EGG-BG-9033, 1991.

30. Davison, B. H., and Thompson, J. E., "Continuous Direct Solvent Extraction of Butanol in a Fermenting Fluidized-bed Bioreactor with Immobilized Clostridium acetobutylicum," Appl. Biochem. Biotechnol. 39/40, 415-26 (1993).

31. Klibanov, A. M., "Enzymes that Work in Organic Solvents," ChemTech 16, 354-59 (1986).

32. Godtfredsen, S. E., Ingvorsen, K., Yde, B., and Andresen, O. "The Scope of Biocatalysts in Organic Chemical Processing," in Biocatalysts in Organic Syntheses, Tramper, J., van der Plas, H. C., and Linko, P. (Eds.), pp. 3-18, Elsevier, Amsterdam, 1985.

33. Caruana, C. M., "Hazardous Waste Management - A Top Priority with EPA," Chem. Eng. Prog. 83(7), 50-53 (1986).

34. Hinchee, R. E., Anderson, B. B., Metting, E. B., and Sayles, G. D., Eds., Applied Biotechnology for Site Remediation, 1, Lewis Publishers, Boca Raton, 1994.

35. Worden, R. M., and Donaldson, T. L., "Dynamics of a Biological Fixed Film for Phenol Degradation in a Fluidized-bed Bioreactor," Biotechnol. Bioeng. 30, 389-412 (1987). 
36. Hinchee, R. E., Alleman, B. C., Hoeppel, R. E., and Miller, R. N., Eds., Hydrocarbon Bioremediation, Lewis Publishers, Boca Raton, 1994.

37. Hinchee, R. E., Downey, D. C., Dupont, R. R., Aggarwal, P., and Miller, R. N., "Enhancing Biodegradation of Petroleum Hydrocarbon through Soil Venting," J. Hazard. Mater., 27, 315-20 (1991).

38. Pedersen, T. A., and Gurtis, J. T., Soil Vapor Extraction Technology Reference Handbook, Environmental Protection Agency Report, EPAV540/2-91/003, 1991.

39. Leahy, J. G., and Colwell, R. R., "Microbial Degradation of Hydrocarbons in the Environment," Microbiol. Rev. 54(3), 305-15 (1990).

40. Gaertner, H. F., and Puigserver, A. J., "Protein-Protein Interaction in Low Water Organic Media," Biotechnol. Bioeng. 36, 601-07 (1990).

41. Brumm, P. J., "Enzymatic Production of Hydrogen Peroxide in a NonAqueous Environment," Biotechnol. Lett. 10, $237-42$ (1988).

42. Scott, C. D., Woodward, C. A., Thompson, J. E., and Blankinship, S. L., "Coal Solubilization by Enhanced Enzyme Activity in Organic Solvents," Appl. Biochem. Biotechnol. 24/25, 799-815 (1990).

43. Miller, D. A., Prausnitz, J. M., and Blanch, H. W., "Kinetics of Lipasecatalyzed Interesterification of Triglycerides in Cyclohexane," Enzyme Microb. Technol. 13, 98-103 (1991).

44. Ramelmeier, R. A., and Blanch, H. W., "Peroxidase-Catalyzed Oxidation of p-Anisidine with Hydrogen Peroxide in Toluene," Biotechnol. Bioeng. 33, 512-17 (1989).

45. Kumakura, M., and Kaetau, I., "Effect of Organic Solvents on Enzymatic Hydrolysis of Celluloses," Z. Naturforsch. 38c, 79-82 (1983).

46. Patil, D. R., Rethwisch, D. G., and Dordick, J. S., "Enzymatic Synthesis of a Sucrose-Containing Linear Polyester in Nearly Anhydrous Organic Media," Biotechnol. Bioeng. 37, 639-46 (1991).

47. Dordick, J. S., Marletta, M. A., and Klibanov, A. M., "Polymerization of Phenols Catalyzed by Peroxidase in Nonaqueous Media," Biotechnol. Bioeng. 30, 31-6 (1987). 
48. Kise, H., Hayabawa, A., and Noritomi, H., "Enzymatic Reactions in Aqueous-Organic Media. IV. Chitin-alpha-Chymotrypsin Complex as a Catalyst for Amino Acid Esterification and Peptide Synthesis in Organic Solvents," Biotechnol. Lett. 9, 543-48 (1987).

49. Larsson, K., Adlercrutz, P., and Mattiasson, B., "Study of Horse Liver Alcohol Dehydrogenase (HLADH) in AOT-Cyclohexane Reverse Micelles," in Biocatalysis in Organic Media, C. Laane, J. Tramper, and M. D. Lilly, Eds., pp. 355-360 Elsevier, Amsterdam, 1987.

50. Sarra, M., Caminal, Gonzalez, G., and Lopez-Santin, J., "Reaction Medium Selection for an Enzymatic Peptide Synthesis in an AqueousOrganic Two-Phase System," Biocatalysis 7, 49-60 (1992).

51. Dordick, J. S., Marletta, M. A., and Klibanov, A. M., "Peroxidase Depolymerize Lignin in Organic Media but not Water," Proc. Natl. Acad. Sci. 83, 6255-57 (1986).

52. Singh, M., and Thomas, M., "Biocatalytic Oxidation of Hydroquinone to pBenzopuinone in a Water-Organic Solvent Two-Phase System," Biotechnol. Lett. 7, 663-64 (1985).

53. Pugniere, M. L., Barry, C., and Previero, A., "A Recirculating Packed-bed Reactor for Enzyme Catalyzed Reactions in Two Liquid-Phase Systems," Biotechnol. Tech. 3, 339-44 (1989).

54. Lortie, R., Villaume, I. Legoy, M. D., and Thomas, D., "Enzymatic Production of Long-Chain Aldehydes in a Fixed Bed Reactor Using Organic Solvents and Cofactor Regeneration," Biotechnol. Bioeng. 33, 229-32 (1989).

55. Harrop, A. J., Hocknull, M. D., and Lilly, M. D., "Biotrasformations in Organic Solvents: A Difference Between Gram-Positive and GramNegative Bacteria," Biotechnol. Lett. 11, 807-10 (1989).

56. Efroymson, R. A., and Alexander, M., "Biodegradation by an Arthrobacter Species of Hydrocarbons Partitioned into an Organic Solvent," Appl. Environ. Microbiol. 57, 1441-47 (1991).

57. Duff, S. J. B., and Murray, W. B., "Oxidation of Benzyl Alcohol by Whole Cells of Pichia pastoria and by Alcohol Oxidase in Aqueous and Nonaqueous Reaction Media," Biotechnol. Bioeng. 34, 153-59 (1989). 
58. Khmelnitskii, Yu. L., Hilhorst, R., and Veeger, C., "Detergentless Microemulsions as Media for Enzymic Reactions. Cholesterol Oxidation Catalyzed by Cholesterol Oxidase," Eur. J. Biochem. 176, 265-71 (1988).

59. De Smet, M. J., Kingma, J., and Witholt, B., "The Effect of Toluene on the Structure and Permeability of the Outer and Cytoplasmic Membranes of Escherichia coli," Biochim. Biophys. Acta 506, 64-80 (1978).

60. Playne, M. J., and Smith, B. R., "Toxicity of Organic Extraction Reagents to Anaerobic Bacteria," Biotechnol. Bioeng. 25, 1251-65 (1983).

61. Lilly, M. D., Brazier, A. J., Hocknull, M. D., Williams, A. C., and Woodley, J. M., "Biological Conversion Involving Water-Insoluble Organic Compounds," in Biocatalysis in Organic Media, C. Laane, J. Tramper, and M. D. Lily, Eds., pp. 3-17, 1987.

62. Roffler, S. R., Randolph, T. W., Miller, D. S., Blanch, H. W., and Prausnitz, J. M., "Extractive Bioconversion with Non-Aqueous Solvents," in Extractive Bioconversions, B. Mattiasson and O. Holst, Eds., pp. 133172, Marcel-Dekker, Inc., 1991.

63. Chem, K. and Arnold, F. H., "Enzyme Engineering for Nonaqueous Solvents: Random Mutagenesis to Enhance Activity of Sublilisin E in Polar Organic Media," Bio/Technol. 9, 1073-77 (1991).

64. Finnerty, W. R., "Organic Sulfur Biodesulfurization in Non-aqueous Media," Fuel 72, 1631-34 (1993).

65. Bar, R., and Gainer, J. L., "Acid Fermentation in Water-Organic Solvent Two Phase Systems," Biotechnol. Prog. 3, 109-14 (1987).

66. Klibanov, A. M., "Enzymatic Catalysis in Anhydrous Organic Solvents," Trends Biochem. Sci. 14, 141-44 (1989).

67. Laane, C., Boeren, S., Vos, K., and Veeger, C., "Rules for Optimization of Biocatalysis in Organic Solvents," Biotechnol. Bioeng. 30, 81-87 (1987).

68. Narayan, V. S., and Klibanov, A. M., "Are Water-Immiscibility and Apolarity of the Solvent Relevant to Enzyme Efficiency?," Biotechnol. Bioeng. 41, 390-93 (1993).

69. van Erp, S. H. M., Kamenskaya, E. O., Khmelnitsky, Yu. L., "The Effect of Water Content and Nature of Organic Solvent on Enzyme Activity in Lowwater Media," Eur. J. Biochem. 202, 379-84 (1991). 
70. Dabulis, K, and Klibanov, A. M., "Dramatic Enhancement of Enzymatic Activity in Organic Solvents by Lyoprotectants," Biotechnol. Bioeng. 41, 566-71 (1993).

71. Reslow, M., Adlercreutz, P., and Mattiasson, B., "Organic Solvents for Bioorganic Synthesis. 1. Optimization of Parameters for a Chymotrypsin Catalyzed Process," Appl. Microbiol. Biotechnol. 26, 1-8 (1987).

72. Goldberg, M., Thomas, D., and Legoy, M-D., Water Activity as a Key Parameter of Synthesis Reactions: The Example of Lipase in Biphasic (Liquid/Solid) Media," Enzyme Microb. Technol. 12, 976-81 (1990).

73. Ferjancic, A., Puigserver, A., and Gaertner, H., "Papain-Catalyzed Polymerization of Amino Acids in Low Water Organic Solvents," Biotechnol. Lett. 13(3), 161-66 (1991).

74. Shield, J. W., Ferguson, H. D., Bommarius, A. S., Hatton, T. A., "Enzymes in Reversed Micelles as Catalysts for Organic Phase Synthesis Reactions," Ind. Eng. Chem. Fundam. 25, 603-612 (1986).

75. Khmelsitsky, Yu. L., Kabanov, A. V., Klyachko, N. L., Levashov, A. V. and Martinek, K., "Enzymatic Catalysis in Reversed Micelles," in Structure and Reactivity in Reversed Micelles, M. P. Pileni, Ed., pp. 230-61, 1989.

76. Matsuura, J., Powers, M. E., Manning, M. C., and Shefter, E., "Structure and Stability of Insulin Dissolved in 1-Octanol," J. Am. Chem. Soc. 115, 1261 (1993).

77. Paradkar, V. M. and Dordick, J. S., "Mechanism of Extraction of Chymotrypsin into Isooctane at Very Low Concentrations of Aerosol OT in the Absence of Reversed Micelles," Biotechnol. Bioeng. 43, 529-40 (1994).

78. van Loosdrecht, M. C. M., Lyklema, J., Morde, W., and Zehnder, A. J. B., "Influence of Interfaces on Microbial Activity," Microbiol. Rev. 54, 75-87 (1990).

79. MacRitchie, F., "Protein Adsorption/Desorption at Fluid Interfaces," Colloids Surf. 41, 25-34 (1989). 
80. Inada, Y., Takahashi, K., Yoshimoto, T., Ajima, A., Matsushima, A., and Saito, Y., "Application of Polyethylene Glycol-Modified Enzymes in Biotechnological Processes: Organic Solvent-Soluble Enzymes," Trends Biotechnol. 4, 190-94 (1986).

81. Gaertner, H. B. and Puigserver, A. J., "Protein-Protein Interaction in Low Water Organic Media," Biotechnol. Bioeng. 36, 601-07 (1990).

82. Goldberg, S., Doyle, R. J., and Rosenberg, M., "Mechanisms of Enhancement of Microbial Cell Hydrophobicity by Cationic Polymers," J. Bacteriol. 172, 5650-54 (1990).

83. Hwang, J. Y., and Arnold, F. H., "Enzyme Design for Nonaqueous Solvents," in Applied Biocatalysis, Vol. 1, H. W. Blanch and D. S. Clark, Eds., pp. 53-86, Marcel Dekker, New York, 1991.

84. Martinez, P., and Arnold, F. H., "Surface Charge Substitutions Increase the Stability of $\alpha$-Lytic Protease in Organic Solvents," J. Am. Chem. Soc. 113, 6336-37 (1991).

85. Amold, F. H., and Zhang, J-H., "Metal-mediated Protein Stabilization," TIBTECH 12, 189-92 (1994).

86. Lily, M.D., and Woodley, J. M., "Biocatalytic Reactions Involving WaterInsoluble Organic Compounds," in Biocatalysts in Organic Syntheses, A. Tramper, H. C. vander Plas and P. Linko, Eds., pp. 179-92, Elsevier, Amsterdam, 1985.

87. Hartdegen, F. J., Cobum, J. M., and Roberts, R. L., "Microbial Desulfurization of Petroleum," Chem. Eng. Prog. 80(5), 63-67 (1994).

88. Tamamushi, B., and Watanabe, N., "The Formation of Molecular Aggregation Structures in Ternary System: Aerosol OTWater/lsooctane," Colloid Polym. Sci. 258, 174-178 (1980).

89. Ju, L.-K, Lee, J. F., and Armiger, W. B., "Effect of the Interfacial Surfactant Layer on Oxygen Transfer Through the OilWater Phase Boundary in Perfluorocarbon Emulsions," Biotechnol. Bioeng. 37, 505511 (1991).

90. Scott, T. C., "Use of Electric Fields in Solvent Extraction: A Review and Prospectus," Separ. Purif. Methods 18, 65-109 (1989). 
91. Scott, T. C., Cosgrove, J. M., DePaoli, D. W., and Sisson, W. G., "Use of the Electrically Driven Emulsion-Phase Contactor for a Biphasic LiquidLiquid Enzyme System: The Oxidation of $p$-Cresol by Aqueous-Phase Horseradish Peroxidase," Appl. Biochem. Biotechnol. (in press).

92. Cowan, D. A., and Planta, A. R., "Biocatalysis in Organic Media," in Biocatalysis at Extreme Temperatures, M. W. Adams and R. M. Kelley, Eds., ACS Symposium Series, Vol. 498, pp. 86-107, American Chemical Society, Washington, D. C. (1992).

93. Hou, C. T., "Propylene Oxide Production from Propylene by Immobilized Whole Cells of Methylosinus sp. CRL 31 in a Gas-solid Bioreactor," Appl. Microb. Biotechnol. 19, 1-4 (1984).

94. Barzana, E., Karel, M., and Klibanov, A. M., "Enzymatic Oxidation of Ethanol in the Gaseous Phase," Biotechnol. Bioeng. 34, 1178-85 (1989).

95. Aaltonen, O., and Rantakyla, M., "Biocatalysis in Supercritical Carbon Dioxide," ChemTech 21, 240-48 (1991).

96. Kamat, S., Barera, J., and Beckman, E. J., "Biocatalytic Synthesis of Acrylates in Organic Solvents and Supercritical Fluids: 1. Optimization of Enzyme Environment," Biotechnol. Bioeng. 40, 158-66 (1992).

97. Hammond, D. A., Karel, M., Klimaanoz, A. M., and Krukonis, V. J., "Enzymic Reactions in Supercritical Gases," Appl. Biochem. Biotechnol. 11, 393-400 (1985).

98. Russell, A. J., Beckman, E. J., and Chaudhary, A. K., "Studying Enzyme Activity in Supercritical Fluids," ChemTech 24(3), 33-37 (1994).

99. Venkatsubraminiam, K., Ed., Immobilized Microbial Cells, ACS Symposium Series 106, American Chemical Society, Washington, D. C., 1979.

100. Woodward, J., Ed., Immobilised Cells and Enzymes, IRL Press, Oxford, 1985.

101. Scott, C. D., "Immobilized Cells - A Review of Recent Literature," Enzyme Microb. Technol. 9, 66-73 (1987). 


\section{INTERNAL DISTRIBUTION}

1. J. B. Ball

2. J. M. Begovich

3. B. A. Berven

4. C. H. Byers

5. B. H. Davison

6. C. W. Gehrs

7. E. Greenbaum

8. F. C. Hartman

9. S. G. Hildebrand

10. K. B. Jacobson

11. R. R. Judkins

12. E. N. Kaufman

13. L. E. McNeese

14. D. E. Reichle

15. S. M. Robinson

16. A. C. Schaffhauser

17-66. T. C. Scott

67. J. Sheffield

68. C. A. Woodward

69. J. Woodward

70. Central Research Library

71-72. Laboratory Records

73. Laboratory Records - RC

74. ORNL Y-12 Technical Library, Document Reference Section

75. ORNL Patent Section

\section{EXTERNAL DISTRIBUTION}

76. F. H. Arnold, California Institute of Technology, Chemical Engineering Department, 391 South Holliston Avenue, Pasadena, CA 91125

77-86. H. W. Blanch, Chemical Engineering Department, University of California, Berkeley, CA

87-96. D. J. Boron, U.S. Department of Energy, 1000 Independence Avenue, Washington, DC 20585

97. R. M. Busche, Bio En-Gene-Er Associates, Inc., 533 Rothbury Road, Wilmington, DE 19803-2439 
98. H. Chum, National Energy Renewable Laboratory, 1617 Cole Boulevard, Golden, CO 80401

99. L. J. Johnson, Idaho National Engineering Laboratory, P. O. Box 1625, Idaho Falls, ID 83415

100-109. A. M. Klibanov, Department of Chemistry, Massachusetts Institute of Technology, Cambridge, MA

110. G. Kulesa, U.S. Department of Energy, 1000 Independence Avenue, SW, Washington, DC 20585

111. O. P. Manley, U.S. Department of Energy, GTN/ER-15, Washington, DC 20545

112. Office of Assistant Manager, U.S. Department of Energy, Oak Ridge Operations Office, P. O. Box 2001, Oak Ridge, TN 37831-8501

113. G. R. Petersen, National Renewable Energy Laboratory, 1617 Cole Boulevard, Golden, CO 80401

114-123. A. J. Russell, Center for Biotechnology, University of Pittsburgh, Pittsburgh, PA

124. P. H. Salmon-Cox, Office of Industrial Technologies, U.S. Department of Energy, Forrestal Building, 1000 Independence Avenue, SW, Washington, DC 20585

125. W. W. Schertz, Argonne National Laboratory, 9700 S. Cass Avenue, Argonne, IL 60439-4816

126. L. B. Schilling, NIST, Advanced Technology Program, Administration Building, Room A430, Gaithersburg, MD 20899-0001

127. P. C. Scott, U.S. Department of Energy, GTN/FE-72, 20300 Century Boulevard, Germantown, MD 20874

128. A. J. Streb, U.S. Department of Energy, EE-20, 1000 Independence Avenue, SW, Washington, DC 20585

129. D. E. Wiley, Office of Industrial Technologies, U.S. Department of Energy, Forrestal Building, 1000 Independence Avenue, SW, Washington, DC 20585

130. C. E. Wyman, National Renewable Energy Laboratory, 1617 Cole Boulevard, Golden, CO 80401 
131-132. Office of Scientific and Technical Information, P. O. Box 62, Oak Ridge, TN 37831 